\title{
Effects of the spermatozoa:oocyte ratio, water volume and water temperature on artificial fertilization and sperm activation of cascudo-preto
}

\author{
Robie Allan Bombardelli', Eduardo Antônio Sanches², Diego Mendes Baggio', Renata Marino \\ Sykora ${ }^{1}$, Bruno Estevão de Souza ${ }^{3}$, Lucélia Tessaro², Pitágoras Augusto Piana ${ }^{1}$
}

\footnotetext{
${ }^{1}$ Curso de Engenharia de Pesca, Universidade Estadual do Oeste do Paraná,Toledo, Paraná, Brazil.

${ }^{2}$ Centro de Aquicultura, Universidade Estadual Paulista, Jaboticabal, São Paulo, Brazil.

${ }^{3}$ Instituto Federal do Paraná, Foz do Iguaçu, Paraná, Brazil.
}

\begin{abstract}
The objective of this study was to evaluate the effects of water volume and water temperature on the sperm motility duration and the number of spermatozoa, and the water volume on the fertilization rates of oocytes of Rhinelepis aspera. Experiments were carried out to evaluate the effect of semen dilutions $\left(1.74 \times 10^{-5}, 1.74 \times 10^{-4}, 1.74 \times 10^{-3}, 1.74 \times 10^{-2}, 1.74 \times 10^{-1}\right.$ and $1.00 \mathrm{~mL}$ of sperm. $\mathrm{mL}^{-1}$ of water) and water temperature $\left(5,10,15,20,25,30,35,40,45\right.$, and $\left.50{ }^{\circ} \mathrm{C}\right)$ on spermatozoa motility duration. In addition, the effects of insemination dose $\left(7 \times 10^{3}, 7 \times 10^{4}, 7 \times 10^{5}, 7 \times 10^{6}\right.$ and $7 \times 10^{7}$ spermatozoa.oocyte $\left.^{-1}\right)$ and water volume $\left(1.0,30.0,60.0,90.0\right.$ and $120.0 \mathrm{~mL}$ water. $2.0 \mathrm{~mL}^{-1}$ oocytes $)$ on the artificial fertilization rates of oocytes were evaluated. The longest sperm motility duration were observed for the semen dilution of $1.74 \times 10^{-5} \mathrm{~mL}$ semen. $\mathrm{mL}^{-1} \mathrm{water}$ and in water at $5^{\circ} \mathrm{C}$. The highest fertilization rates were obtained for insemination doses between $7.00 \times 10^{3}$ and $1.23 \times 10^{7}$ spermatozoa. oocyte $^{-1}$ and water volume of $28.11 \mathrm{~mL}$ water. $2.0 \mathrm{~mL}^{-1}$ oocytes.
\end{abstract}

Key Words: fish, Loricariidae, oocyte, reproduction, semen

\section{Introduction}

Cascudo-preto (Rhinelepis aspera, Agassiz, 1829) is a species of fish that belongs to the family Loricariidae (Graça \& Pavanelli, 2007). In Brazil, it is found in the São Francisco and Paraná basins (Armbruster, 1998). The reproduction of this species is limited to lotic environments (Suzuki et al., 2000). It undergoes gonadal blockage and does not reproduce naturally in captivity and its reproduction must be induced with hormones (Zaniboni Filho \& Weingartner, 2007).

The knowledge about the artificial reproduction of this species may be relevant for the development of technological packages (López, 2005) for offspring production to meet the ornamental market demands (Hayashi et al., 2002; Guerreiro et al., 2011) and the storage or restocking programs (Carolsfeld et al., 2003). The storage or restocking practices are important to promote the conservation of biodiversity in damaged populations (Miranda et al., 2000) provoked by the destruction of habitats, the obstruction of migration routes, pollution and overfishing. As a result of anthropogenic actions, $R$. aspera is a threatened species in some regions of Brazil (Mikich \& Bérnils, 2004).

Although previous research had been suggested as relatively efficient reproductive protocols to $R$. aspera (Sato et al., 1998), some important aspects about sperm activation and artificial fertilization still require further studies. Some priorities could be the use of adequate sperm dosages, providing an adequate fertilization medium and the use of broodfish with high-quality gametes.

Usually, the procedures of artificial reproduction of fish are performed by dry artificial fertilization (Woynarovich \& Horváth, 1983). However, this method has limited efficiency and large variations. Additionally, the application of improper amounts of sperm and water result in reduced artificial fertilization rates (Cherenguini et al., 1999). Thus, the control of these parameters will allow an improvement in the success of reproductive procedures and promote a rational use of gametes, limiting the number of breeders in fish farming and reducing the production costs (Bombardelli et al., 2006).

The objective of the present study was to evaluate the effects the water volume and water temperature on the sperm motility duration and the effects of the spermatozoa: oocyte ratio and the water volume on the fertilization rates of Rhinelepis aspera.

\section{Material and Methods}

This study was carried out at Laboratório de Tecnologia da Reprodução de Animais Aquáticos Cultiváveis (LATRAAC), Universidade Estadual do Oeste do Paraná (UNIOESTE), Toledo, Paraná state, Brazil. 
Females with soft and rounded abdomen, with uniform oocyte coloration and size and males releasing sperm under slight abdominal pressure were selected during the reproductive period. Females and males were taken to the laboratory and weighed individually, marked and separated by sex into two tanks of $1,500 \mathrm{~L}$. The water was constantly renewed $\left(750 \mathrm{~L} \cdot \mathrm{h}^{-1}\right)$.

Initially, five males $(1,286 \pm 162 \mathrm{~g})$ and five females $(1,340 \pm 283 \mathrm{~g})$ of $R$. aspera were used to evaluate (a) the effects of spermatozoa:oocyte ratio on the oocyte artificial fertilization rate and (b) the effects of water volume:sperm volume ratio on the spermatozoa activation process.

Males and females were treated with two dosages of carp pituitary extract (CPE). The first dosage had $0.5 \mathrm{mg}$ of CPE.kg of breeders ${ }^{-1}$. The second dosage was applied 12 hours later, with $5.0 \mathrm{mg}$ of CPE. $\mathrm{kg}^{-1}$ of breeders (Woynarovich \& Horváth, 1983). Gametes were collected after 10 hours at a water temperature of $24 \pm 1^{\circ} \mathrm{C}$ ( 240 degreehours) (Sato et al., 2003).

Males were individually stripped to collect the sperm in graduated test tubes $( \pm 0.1 \mathrm{~mL})$. After measuring the total released sperm volume, the male gametes were stored in refrigerator at $13{ }^{\circ} \mathrm{C}$ (Sanches et al., 2011b). The sperm collected from all breeders were mixed and analyzed. The sperm concentrations (spermatozoa. $\mathrm{mL}^{-1}$ ) were determined by counting sperm cells in a Neubauer hematimetric chamber (Wirtz \& Steinmann, 2006). The sperm survival rate was evaluated by the eosin-nigrosin staining method (Blom, 1950) by mixing $30 \mu \mathrm{L}$ sperm and $90 \mu \mathrm{L}$ of each dye and preparation of a smear (Sanches, 2007). The material was visualized at 400X magnification (light microscopy). Overall, 400 spermatozoa were assessed. Pink cells were considered dead, whereas unstained cells were live. For the sperm motility duration test, $5.0 \mu \mathrm{L}$ of sperm were diluted in $200 \mu \mathrm{L}$ water at $27^{\circ} \mathrm{C}$ (semen:water volume ratio of 1:40). After dilution, $5 \mu \mathrm{L}$ of this mixture were used to evaluate the time necessary for $50 \%$ of spermatozoa to lose their motility. These analyses were carried out under light microscopy at 400X magnification (Sanches, 2007). All males released sperm $(8.06 \pm 6.67 \mathrm{~mL}$ of sperm, $1.90 \times 10^{10} \pm 0.09 \times 10^{10}$ spermatozoa. $\mathrm{mL}^{-1}, 98.77 \pm 3.45 \%$ of live spermatozoa, $21.25 \pm 0.23 \mathrm{~s}$ sperm motility duration).

The oocytes collected from each female were mixed to compose the samples for artificial fertilization assays. A randomized experimental design with five spermatozoa: oocyte ratios $\left(7 \times 10^{3}, 7 \times 10^{4}, 7 \times 10^{5}, 7 \times 10^{6}\right.$, and $7 \times 10^{7}$ spermatozoa.oocyte ${ }^{-1}$ ) and four repetitions was used. Each $2.5 \mathrm{~L}$ incubator containing $2.0 \mathrm{~mL}$ of non-hydrated oocytes ( $\pm 1,420$ oocytes), later fertilized, was considered an experimental unit. The activation of gametes and fertilization were performed in $180 \mathrm{~mL}$ plastic containers through the addition of $30 \mathrm{~mL}$ of water at $27^{\circ} \mathrm{C}$ for one minute under slow homogenization (Sanches et al., 2011a). Water at $27^{\circ} \mathrm{C}$ from an artesian well $(\mathrm{pH}=6.8$; dissolved oxygen $=4.26 \mathrm{mg} . \mathrm{L}^{-1} ;$ nitrate $=0.29 \mathrm{mg} . \mathrm{L}^{-1}$; nitrite $=$ $0.0038 \mathrm{mg} . \mathrm{L}^{-1}$; ammonia $=0.126 \mathrm{mg} \cdot \mathrm{L}^{-1}$; alkalinity $=$ $49.815 \mathrm{mg} \mathrm{CaCO} 3 . \mathrm{L}^{-1}$ ) was used as activating solution. The eggs were placed in $20 \mathrm{PVC}$ conical experimental incubators with $2.5 \mathrm{~L}$ of water. After fertilization, the water from experimental units was maintained at $27.0 \pm 1.0{ }^{\circ} \mathrm{C}$ by an electric water heating system. Twelve hours after activation of gametes, the artificial fertilization was measured by counting three samples with 400 eggs from each experimental unit.

The mixed sperm from the same five males was used to assess the effects of water:sperm volume ratio on sperm motility duration. The same water used in the fertilization assay was used as sperm activating solution. A randomized experimental design with six water:sperm volume ratios and three repetitions were used. The water:sperm volume ratio tested (corresponding to the same dilution rate from the spermatozoa:oocyte ratio assay) were $1.74 \times 10^{-5}, 1.74 \times 10^{-4}$, $1.74 \times 10^{-3}, 1.74 \times 10^{-2}, 1.74 \times 10^{-1}$ and $1.00 \mathrm{~mL}$ of sperm.mL of water ${ }^{-1}$. The sperm activations were carried out in $180 \mathrm{~mL}$ plastic recipients.

In the second assay, (a) the effects of water volume used for the activation of gametes on the oocyte fertilization rate and (b) the temperature of water on the sperm motility duration were assessed. Procedures for the selection of breeders, hormonal induction, collection and evaluation of the gametes and artificial fertilization were carried out as in the previous experiments. However, another five males $(1,215 \pm 87.37 \mathrm{~g})$ and five females $(1,360 \pm 280.80 \mathrm{~g})$ were used. After hormonal induction, the males released $8.95 \pm 3.93 \mathrm{~mL}$ of semen, containing $1.89 \times 10^{10} \pm 0.11 \times 10^{10}$ spermatozoa. $\mathrm{mL}^{-1}$ and $95.92 \pm 4.23 \%$ live sperms and had sperm motility duration of $19.19 \pm 0.84 \mathrm{~s}$.

The experimental design was similar to the previous one. However, five volumes of water were assessed on gamete activation and oocyte artificial fertilization rate. Volumes of $1.0,30.0,60.0,90.0$ or $120.0 \mathrm{~mL}$ water. $2 \mathrm{~mL}$ non-hydrated oocytes $^{-1}$ were assessed. The same fertilization procedures described above were employed using 1,014 oocytes per experimental unit. The ratio of 208,200 spermatozoa. oocyte $^{-1}$ (results from the 1st assay) was used.

Similarly to the previous trial, the mixed sperm from the same five males was used to assess the effects of water temperature on sperm motility duration. A randomized experimental design with ten water temperatures and three repetitions was used. The water temperatures of $5,10,15$, $20,25,30,35,40,45$, and $50^{\circ} \mathrm{C}$ were employed to evaluate 
the sperm motility duration. The spermatozoa activation process was carried out in $180.0 \mathrm{~mL}$ plastic recipients (Sanches et al., 2011a) using $25 \mu \mathrm{L}$ semen. $\mathrm{mL}^{-1}$ water.

The fertilization rate and sperm motility duration were submitted to regression analysis at $5 \%$ significance. Analyses were carried out with software SAEG (Sistema para Análises Estatísticas, version 7.1). Fertilization rates from the last assay (water volume:oocyte volume) were analyzed by the following model: $F R=$ aVolume $e^{\text {cllolume }}$, in which: $F R=$ fertilization rate $(\%)$; Volume $=$ water volume $(\mathrm{mL}) ; a, b$, and $c=$ constants; and $e=2.718282$. This model was linearized by a natural log transformation. The parameters were estimated and evaluated at a significance level of $5 \%$ with the multiple linear regression protocol. The software used was Statistica $7.0^{\circledR}$.

\section{Results and Discussion}

The fertilization rates of $R$. aspera oocytes were affected $(\mathrm{P}<0.05)$ by the spermatozoa:oocyte ratio. The results show a tendency to plateau, with stable fertilization rate as a function of increasing spermatozoa:oocyte ratios between $7.0 \times 10^{3}$ and $1.23 \times 10^{7}$ spermatozoa.oocytes $^{-1}$, resulting in a theoretical fertilization rate of $71.96 \%$ (Figure 1). Above this level the results showed a linear tendency, inversely proportional to the increase of the spermatozoa:oocyte ratio (Figure 1).

Bombardelli et al. (2006) observed the plateau tendency on the fertilization rates of Rhamdia quelen oocytes when the spermatozoa:oocyte ratios were increased. However, despite the initial increase in the fertilization rates, proportionally with the increase in the spermatozoa: oocyte ratios, they observed a beginning of plateau after

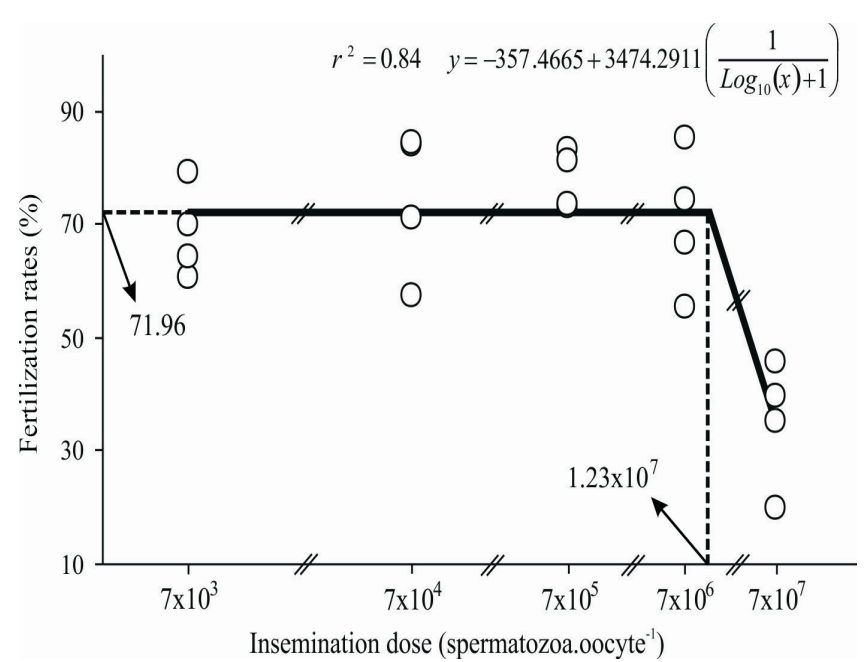

Figure 1 - Artificial fertilization rate of $R$. aspera oocytes according to the increasing spermatozoa:oocyte ratio.
90,000 spermatozoa.oocyte $^{-1} \quad(86.68 \%$ of fertilization $)$ and no additional effect until $2.0 \times 10^{7}$ spermatozoa.oocyte ${ }^{-1}$. Rurangwa et al. (1998), suggested that the best fertilization rates occur within a wide insemination dose range. In addition, the optimal spermatozoa:oocyte ratio presents a species-specific relationship, such as the Salminus brasiliensis, which requires 30,722 spermatozoa:oocyte to promote high fertilization rates (Sanches, 2007) and Piaractus mesopotamicus, which requires 7,000 to $7,000,000$ spermatozoa:oocyte ratio for the same result (Sanches et al., 2007).

The fertilization rates of $R$. aspera oocytes were also affected $(\mathrm{P}<0.05)$ by the different water volumes (Figure 2 ) used during the activation of gametes. The fertilization rate (\%) increased quickly with the increase in the water volume $(\mathrm{mL})$. The fertilization rates were adjusted by the model $F R=70.1851^{*}$ Volume $^{0.078729} * e^{-0.0028 * \text { Volume }}$, showing that $2 \mathrm{~mL}$ of oocytes, when fertilized with 208,200 spermatozoa. oocyte $^{-1}$ required $28.11 \mathrm{~mL}$ of water to promote the best theoretical fertilization rate corresponding to $84.36 \%$. Higher volume of water results in damage in the artificial fertilization rates.

According to Rurangwa et al. (2004), factors such as gamete contact time and the fertilization protocol may influence fertilization rates. However, it is worth considering that some characteristics, such as oocyte size, spermatozoa swimming distance, sperm motility duration and micropyle closing time, are determinants in the procedures of application of insemination doses (Billard \& Cosson, 1992; Suquet et al., 1995) and are sharply different for the fish species teleosts (Godinho, 2007).

The results from experiment of spermatozoa:oocyte ratio (Figure 1) suggest that high spermatozoa/sperm

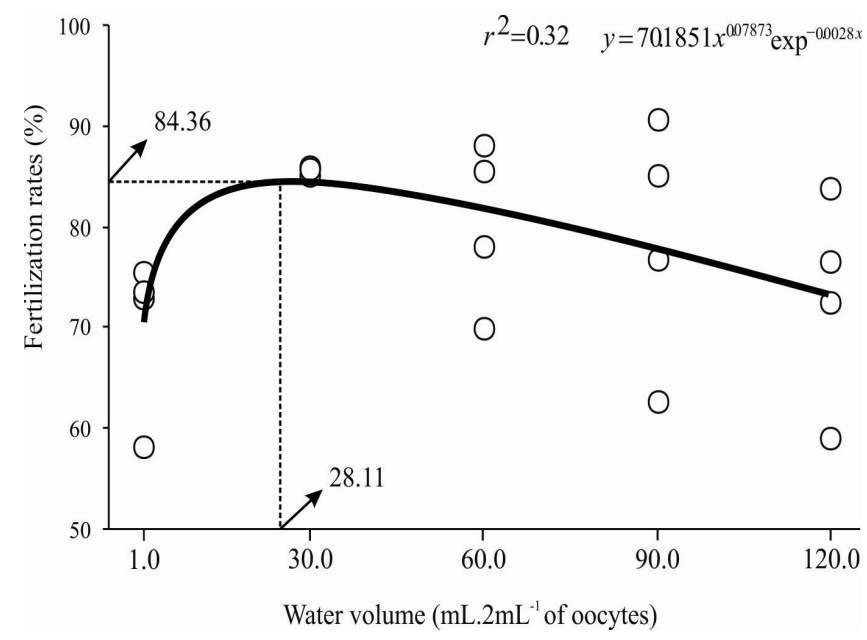

Figure 2 - Artificial fertilization rate of $R$. aspera oocytes by the increasing water volume during activation of gametes, using a 208,200 spermatozoa:oocyte ${ }^{-1}$ ratio. 
concentrations in a fertilizing medium promote a low fertilization rate. These effects can be related with the inefficient reduction of the osmolarity of the fertilization medium (Alavi et al., 2007) when high sperm quantities are used, which negatively affected the spermatozoa activation or did not afford an adequate fertilization medium (Chereguini et al., 1999). The inadequate medium can be related with the availability of oxygen to ensure the energetic or enzymatic activity (Lahnsteiner et al., 1998; Weingartner \& Zaniboni-Filho, 2007) during the spermatozoa movement.

On the other hand, damages in fertilization rates when water volumes were higher than $28.11 \mathrm{~mL}$ of water. $2 \mathrm{~mL}^{-1}$ of oocyte (Figure 2) could be related to the excessive water volume employed, which caused a high dilution of sperm in the fertilizing medium. These dilution effects may have resulted in high dispersion of spermatozoa, thus hindering or reducing the probability of spermatozoa catch up the micropyle (Chereguini et al., 1999), during the short activating period.

The experiment to assess the water volume:sperm volume ratio on the activation of spermatozoa showed that the duration of sperm motility was proportional $(\mathrm{P}<0.05)$ to the increase in the sperm dilution (Figure 3 ). The greatest motility of spermatozoa $(24.61 \pm 1.50 \mathrm{~s})$ was verified at $1.74 \times 10^{-5} \mathrm{~mL}$ semen.mL water ${ }^{-1}$ (Figure 3), whereas at $1.0 \mathrm{~mL}$ semen.mL of water ${ }^{-1}$, the motility was not assessed because the spermatozoa had not been activated. Such results are common in other neotropical fish species, such as the Piaractus mesopotamicus (Sanches et al., 2007). According to Billard \& Cosson (1992), the sperm concentration in the fertilizing medium and the volume of diluents are the main triggers of spermatozoa activation. Therefore the sperm:water volume ratio is a limiting factor

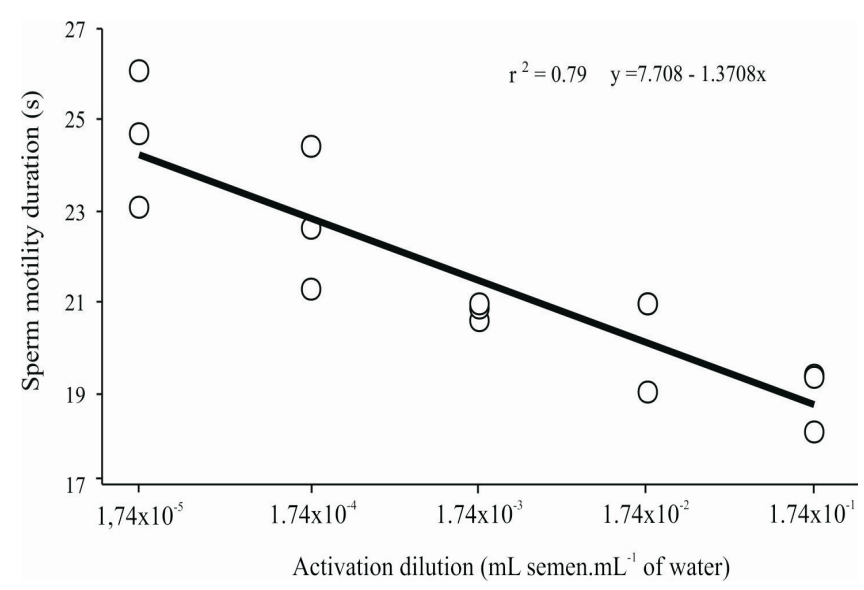

Figure 3 - Spermatozoa motility duration from $R$. aspera sperm activated by different water volumes. in motility of spermatozoa, mainly becayse the spermatozoa activation process is initiated by the reduction of the osmotic concentration of the medium (Billard et al., 1995). Billard \& Cosson (1992) suggest that for the complete activation of spermatozoa, the dilution must be higher than 1:1000 to ensure an efficient change in semen viscosity. Despite these results showing that high sperm dilution promotes a longer period of spermatozoa motility, care should be taken during the artificial fertilization procedures to avoid dispersion of the spermatozoa in the fertilizing medium and final damage in the fertilization process.

The water temperature affected the spermatozoa motility duration $(\mathrm{P}<0.05)$, showing an inversely proportional linear trend (Figure 4$)$. The high water temperature led to a reduction of sperm motility duration and the temperature lower than $5{ }^{\circ} \mathrm{C}$ promoted the longer time of spermatozoa activation. Although R. aspera is a tropical fish, the best spermatozoa activation times were those for low activating solution temperatures. Water at low temperature might not always be used to activate the $R$. aspera gametes in artificial fertilization procedures, because low temperatures can cause damage to the oocytes or to the embryos in the initial phases of development.

Alavi \& Cosson (2005) reported some changes in spermatozoa motility as a function of water temperature. In some species, the high water temperatures apparently lead to reduction in the total spermatozoa motility time, but this reduction is compensated by a higher spermatic speed when compared with those spermatozoa activated at low temperatures and with longer motility duration. The reduction of the total time of spermatozoa motility can be due to the limited energetic resources and the influence of the temperature on the spermatozoa activation process.

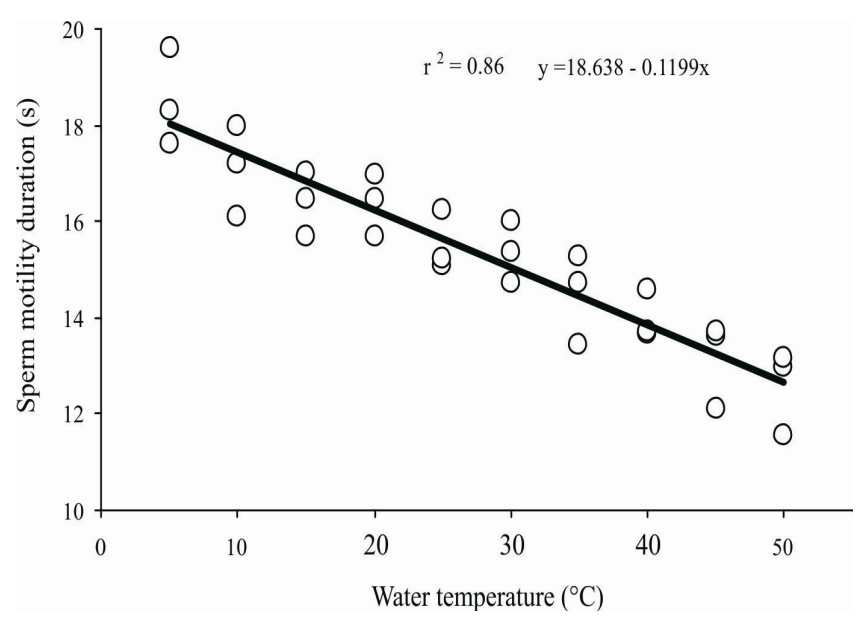

Figure 4 - Spermatozoa motility duration from $R$. aspera sperm activated by water at different temperatures. 
The results from this research suggest that the sperm dilution is one of the main factors affecting the fertilization of oocytes and spermatozoa motility duration of $R$. aspera. Therefore, the use of procedures combining the interaction of the sperm density, the water volume and water temperature can be useful to achieve high fertilization rates. The correct use of these procedures will be fundamental for the development of the artificial reproduction and the technology of artificial production of $R$. aspera, which is an important fish species to the fisheries and aquaculture of Latin America. This knowledge will promote improvement of breeding procedures through the optimization of the use of the gametes and will possibly be a useful tool to help the programs of biodiversity conservation.

\section{Conclusions}

The artificial fertilization procedure affected the success of artificial reproduction of Rhinelepis aspera. The maximal optimization of sperm use can be obtained with $7.00 \times 10^{3}$ spermatozoa.occyte ${ }^{-1}$. However, the water volume and the water temperature must be controlled because they affect the activation of spermatozoa and the fertilization of oocytes.

\section{Acknowledgements}

The authors thank Centro de Pesquisa em Aqüicultura Ambiental (CPAA).

\section{References}

ALAVI, S.M.H.; COSSON, J. Sperm motility in fishes. (I) Effects of temperature and $\mathrm{pH}$ : a review. Cell Biology International, v.29, p.101-110, 2005.

ALAVI, S.M.H.; RODINA, M.; POLICAR, T. et al. Semen of Perca fluviatilis L.: Sperm volume and density, seminal plasma indices and effects of dilution ratio, ions and osmolality on sperm motility. Theriogenology, v.68, p.276-283, 2007.

ARMBRUSTER, J.W. Phylogenetic relationships of the suckermounth armored catfishes of Rhinelepis group (Loricariidae: Hypostominae). Copeia, v.3, p.620-636, 1998.

BILLARD, R.; COSSON, J.; CRIM, L.W. et al. Sperm physiology and quality. In: BROMAGE N.R.; ROBERTS, R.J. (Eds.) Broodstock management and egg and larval quality. Oxford: Blackwell Science, 1995. p.25-52

BILLARD, R.; COSSON, M.P. Some problems related to the assessment of sperm motility in freshwater fish. The Journal of Experimental Zoology, v.261, p.22-31, 1992.

BLOM, E.A. One-minute live-dead sperm stain by means of EosinNigrosin. Fertility and Sterility, v.1, p.176-177, 1950.

BOMBARDELLI, R.A.; MÖRSCHBÄCHER, E.F.; CAMPAGNOLO, R. et al. Dose inseminante para fertilização artificial de ovócitos de jundiá Rhamdia quelen (Quoy \& Gaimard, 1824). Revista Brasileira de Zootecnia, v.35, n.4, p.1251-1257, 2006.

CAROLSFELD, J.; GODINHO, H.P.; ZANIBONI FILHO, E. et al. Cryopreservation of sperm in Brazilian migratory fish conservation. Journal of Fish Biology, v.63, p.472-489, 2003.
CHEREGUINI, O.; DE LA BANDA, I.G.; RASINES, I. et al. Artificial fertilization in turbot, Scopothalmus maximus, (L.): different methods and determination of the optimal sperm-egg ratio. Aquaculture Research, v.30, p.319-324, 1999.

DELARIVA, R.L.; AGOSTINHO, A.A. Relationship between morphology and diets of sixneotropical loricariids. Journal Fish Biology, v.58, p.832-847, 2001.

GRAÇA, W.J.; PAVANELLI, C.S. Peixes da planície de inundação do alto rio Paraná e áreas adjacentes. Maringá: EDUEM, 2007. $241 \mathrm{p}$.

GODINHO, H.P. Estratégias reprodutivas de peixes aplicadas à aqüicultura: bases para o desenvolvimento de tecnologias de produção. Revista Brasileira de Reprodução Animal, v.31, n.3, p.351-360, 2007.

GUERREIRO, L.R.J.; DIAS, J.A.D.; FORNARI, D.C. et al. Desempenho de pós larvas de cascudo preto (Rhinelepis aspera), alimentadas com naúplios de artemia e ração oferecida em saches. Semina, v.32, n.2, p.781-788, 2011.

HAYASHI, C.; SOARES, C.M.; GALDIOLI, E.M. et al. Uso de plâncton silvestre, fermento fresco e levedura desidratada na alimentação de larvas do cascudo chinelo, Loricariichthys platymetopon (Isbrüchen \& Nijssen, 1979) (Osteichthyes, Loricariidae). Acta Scientiarum, v.24, n.2, p.541-546, 2002.

LAHNSTEINER, F.; BERGER, B.; WEISMANN, T. et al. Determination of semen quality of the rainbow trout, Oncorhynchus mykiss, by sperm motility, seminal plasma parameters, and spermatozoal metabolism. Aquaculture, v.163, p.163-181, 1998.

LÓPEZ, C.M. Crescimento de larvas de cascudo-preto (Rhinelepis aspera) Spix \& Agassiz, 1829 (Osteichthyies: Siluriformes, Loricariidae), submetidos a diferentes dietas alimentares. 2005. 46f. Dissertação (Mestrado em Aquicultura) - Universidade Estadual Paulista "Júlio de Mesquita Filho", Jaboticabal.

MIKICH, S.B.; BÉRNILS, R.S. [2004]. Livro vermelho da fauna ameaçada no Estado do Paraná. Available at: <http://www. pr.gov.br/iap> Accessed on: May 3, 2010.

MIRANDA, L.E.; AGOSTINHO, A.A.; GOMES, L.C. Appraisal of the selective properties of gill nets and the implications for yield and value of the fisheries at Itaipu Reservoir, Brazil-Paraguay. Fisheries Research, v.45, p.105-116, 2000.

RURANGWA E.; KIME, D.E.; OLLEVIER, F. et al. The measurement of sperm motility and factors affecting sperm quality in cultured fish. Aquaculture, v.234, p.1-28, 2004.

RURANGWA, E.; ROCLANTS, I.; HUYSKENS, G. et al. The minimum effective spermatozoa:egg ratio for artificial insemination and the effects of mercury on sperm motility and fertilization ability in (Clarias gariepinus). Journal of Fish Biology, v.53, p.402-413, 1998.

SANCHES, E.A. Dose inseminante para fertilização artificial de ovócitos de dourado (Salminus brasiliensis). 2007. 73f. Monografia (Graduação em Engenharia de Pesca) - Universidade Estadual do Oeste do Paraná, Toledo.

SANCHES, E.A.; BAGGIO, D.M.; BOMBARDELLI, R.A. et al. Efeito da relação volume de sêmen/volume de água sobre o tempo de ativação espermática em Pacu (Piaractus mesopotamicus). In: CONGRESSO NACIONAL DE ENGENHARIA DE PESCA, ENGENHARIA QUÍMICA E QUÍMICA, 1., 2007, Toledo. Anais... Toledo: Centro de Engenharias e Ciências Exatas da Universidade Estadual do Oeste do Paraná, [2007] (CD-ROM).

SANCHES, E.A.; NEUMANN, G.; BAGGIO, D.M. et al. Time and temperature on the storage of oocytes from jundiá catfish, Rhamdia quelen. Aquaculture, v.319, p.453-458, 2011a.

SANCHES, E.A.; NEUMANN, G.; TOLEDO, C.P.R. et al. Temperature and storage period over spermatic parameters of jundiá, Rhamdia quelen (Quoy \& Gaimard, 1824). Aquaculture Research, 2011b, doi: 10.1111/j.1365-2109.2011.03056.x

SATO, Y.; FENERICH-VERANI, N.; VERANI, J.R. et al. Induced reproduction and reproductive characteristics of Rhinelepis aspera Agassiz, 1829 (Osteichthyies: Siluriformes, Loricariidae). Brazilian Archives Biology and Technology, v.41, p.309-314, 1998. 
SATO, Y.; FENERICH-VERANI, N.; GODINHO, H.P. Reprodução Induzida de Peixes da Bacia do São Francisco. In: GODINHO, H.P.; GODINHO, A.L. (Eds.). Águas, peixes e pescadores do São Francisco das Minas Gerais. Belo Horizonte: PUC-Minas, 2003. p.275-290.

SUQUET, M.; BILLARD, R.; COSSON, J.C et al. Artificial insemination in turbot (Scophthalmus maximus): determination of the optimal sperm to egg ratio and time of gamete contact. Aquaculture, v.133, p.83-90, 1995.

SUZUKI, H.I.; AGOSTINHO, A.A.; WINEMILLER, K.O. Relationship between oocyte morphology and reproductive strategy in loricariid catfishes of the Paraná River, Brazil. Journal Fish Biology, v.57, p.791-807, 2000.
WIRTZ, S.; STEINMANN, P. Sperm characteristics in perch Perca fluviatilis L. Journal of Fish Biology, v.68, p.1896-1902, 2006. WEINGARTNER, M.; ZANIBONI FILHO, E. Efeito do curto período de estocagem dos ovócitos e tempo de enxágüe da água de ativação dos gametas na reprodução de dourado Salminus brasiliensis. In: CONGRESSO BRASILEIRO DE PRODUÇÃO DE PEIXES NATIVOS DE AGUA DOCE, 1., 2007, Dourados. Anais... Dourados: Embrapa, [2007]. (CD-ROM).

WOYNAROVICH, E.; HORVÁTH, L. Propagação artificial de peixes de águas tropicais: manual de extensão. Brasília: Escopo, 1983. 220p.

ZANIBONI FILHO, E.; WEINGARTNER, M. Técnicas de indução da reprodução de peixes migradores. Revista Brasileira de Reprodução Animal, v.31, n.3, p.367-373, 2007. 